http://kitaibelia.unideb.hu/

ISSN 2064-4507 (Online) • ISSN 1219-9672 (Print)

(C) 2015, Department of Botany, University of Debrecen, Hungary

20 (1): 55-58.; 2015

DOI: $10.17542 /$ kit.20.55

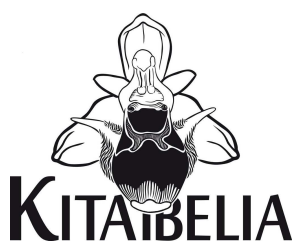

\title{
Sorbus udvardyana Somlyay \& Sennikov a Balaton-felvidék keleti dolomitterületén
}

\author{
BAUER Norbert \\ MTM Növénytár, H-1476 Budapest, Pf. 222; bauer@bot.nhmus.hu
}

\section{Sorbus udvardyana Somlyay \& Sennikov in the eastern part of the Balaton Uplands}

\begin{abstract}
Related to distribution of $S$. aria s.l. $\times S$. torminalis hybrid taxa in the eastern part of the Balaton Uplands just data of "S. balatonica” is in the literature based on collection of Ádám Boros (Kárpáti 1960). In the summer of 2014 the author found and mapped a few (sub)populations of $S$. aria s.l. $\times$ S. torminalis at Lovas (Királykúti-völgy, Atya-hegy, CEU: 8973.4) and Felsőörs (Malom-völgy, Kopasz-tető, CEU: 8973.4) villages. Based on leaf-morphological traits the specimens were identified as S. udvardyana.
\end{abstract}

Keywords: apomictic taxa, Balaton Uplands, flora of Hungary, Sorbus balatonica, S. bakonyensis, nothosubgenus Tormaria

Összefoglalás - A Balaton-felvidék keleti részéről a $S$. aria s.l. $\times$ S. torminalis hibrid eredetű taxonjai közül a szakirodalomban a „S. balatonica” jelenik meg (Felsőörs: „Káposzta-tető”), Boros Ádám gyűjtésére hivatkozva (KÁRPÁTI 1960). 2014 nyarán, ezen a lelőhelyen, a felsőörsi Kopasz-tetőn és a lovasi Atya-hegyen folytatott flóratérképezési munka során kiderült, hogy a korábbi $S$. balatonica adat egy másik taxonra vonatkozik. A térképezett egyedek levélmorfológiai alapon a $S$. udvardyana taxonnal azonosíthatók.

Kulcsszavak: apomiktikus kisfajok, Balaton-felvidék, Magyarország flórája, Sorbus balatonica, S. bakonyensis, nothosubgenus Tormaria

\section{Bevezetés}

A Bakony-vidék Sorbus-kutatásai BoRBÁs (1900), JÁVORKA (1927) és KÁRPÁTI (1948, 1950a, $b$, 1953, 1960) munkásságát követően az elmúlt években újabb lendületet kaptak. Új bennszülött apomiktikus taxonokat írtak le, fokozatosan tisztul a jellemző fajok, alakok elterjedésével kapcsolatos kép (BARABITS 2007, NÉMETH 2007, 2012, 2013, 2014a, b, SOMLYAY \& SENNIKOV 2014).

SOMLYAY \& SENNIKOV (2014) a Sorbus bakonyensis KovÁTS (1998) általi tipizálására hivatkozva megállapítják, hogy a $S$. bakonyensis nevet a Márkó feletti Kopasz-tetőn élő taxonra kell alkalmazni. A Déli-Bakonyból, a Keszthelyi-hegységből és a Balaton-felvidék bazalt tanúhegyeiről korábban S. bakonyensis néven tárgyalt fajt (vö. BARABITS 2007, NÉMETH 2010, 2012, 2014a, b) S. udvardyana néven írják le és tipizálják. SoMLYAY \& SENNIKOV (2014) ugyanakkor megjegyzik, hogy a $S$. udvardyana elterjedési területén morfológiailag némileg változatos, s a különböző alakok taxonómiai rangjának megítéléséhez további vizsgálatok szükségesek (a faj leírását éppen ezért a locus classicus-szon, a Tóti-hegyen élő példányok alapján adják). NÉMETH (2014a) a Keszthelyi-hegységből jelez leíratlan alakokat, és felhívja a 
figyelmet arra, hogy további mintavételezések és genetikai vizsgálatok szükségesek a dunántúli Sorbus populációk taxonómiai és leszármazási kérdéseinek tisztázásához.

\section{Eredmények}

2014. június 29-én a Lovas feletti Piarista-erdő, Királykúti-völgy térségének flóra- és vegetációtérképezése során egy $S$. aria s.l. $\times S$. torminalis taxon populációjára lettem figyelmes. Mintegy tucatnyi példány a lovasi Atya-hegy meredek északi lejtőjén, a Királykútivölgy felső harmadában került elő (CEU: 8973.4). A következő héten (2014.07.03.) a szomszédos völgy (Felsőörs: Malom-völgy) hasonló élőhelyeinek szisztematikus terepbejárása során a szóban forgó Sorbus-taxon újabb populációjára bukkantam. A felsőörsi Kopasz-tető (8973.4) meredek északi letörésein, sziklás lejtőin, a Malom-völgy felső harmadában (elsősorban a bekerített Vízmű terület felett) több tucat egyede él.

A Balaton-felvidék keleti részéról, mégpedig a fenti területről, KÁRPÁTI (1960) monográfiájában egy $S$. balatonica adat található, Boros Ádám gyűjtéséből (Felsőörs: „Káposzta-tető" = Kopasz-tető). Bár Boros herbáriuma a Növénytárba került, a szóban forgó felsőörsi „S. balatonica” példány jelenleg (2014. szeptember-október) nem található meg a gyűjteményben. Boros Ádám útinaplói (BoRos 1957) alapján az adat egy 1957. augusztus 9-i megfigyelés és gyűjtés eredménye. Az útinaplóban azonban nem „balatonica” néven, hanem, egy későbbi ceruzás bejegyzéssel, „,bakonyensis" néven szerepel.

$\mathrm{Az}$ elmúlt években Somlyay Lajossal folytatott keszthelyi-hegységi és déli-bakonyi Sorbus-gyűjtéseink tapasztalatai alapján az Atya-hegyen és a Kopasz-tetőn előkerült növényt nem $S$. balatonica-ként, hanem $S$. udvardyana-ként azonosítottam. A gyüjtött, érett termés nélküli példányokat, a levelek morfológiája alapján, a faj leírója, Somlyay Lajos is Sorbus udvardyana-nak tartja.

A S. udvardyana lovasi és felsőörsi populációjának élőhelye Fago-Ornetum, Festuco pallenti-Brometum pannonici és Cotino-Quercetum pubescentis érintkezési zónájaként írható le, az idősebb egyedek Fago-Ornetum-ban élnek. A Malom-völgyben a fafaj néhány példánya a völgy északnyugati részén, lankás lejtőn, mészkedvelő tölgyesben (Vicio sparsifloraeQuercetum pubescentis) is előfordul. Mindkét területen történt korábban feketefenyvesítés, de a feketefenyő példányok idősek, többnyire már ritkásan állnak, így kevésbé veszélyeztetik az élőhelyet. A populációk értékét növeli, hogy mindkét előfordulási helyen találhatók egészséges, idősebb, fatermetű példányok (15 cm-t meghaladó törzsátmérővel), és egy-egy 25-30 cm-t meghaladó törzsátmérőjű egyed is előkerült.

A populációkat ősszel, termésérlelés idején is felkerestem (Felsőörs, 2014.09.05., Lovas, 2014.09.26.). Folytattam a példányok feltérképezését, a megtalált egyedek alapján elkészítettem a populációk ponttérképét (1. ábra). 2014-ben az idősebb példányok közül is igen kevés hozott termést, és a csapadékos nyári és kora őszi időjárás miatt a termések nagyrészt "betegek" voltak.

A S. udvardyana a Bakony-vidéken a legnagyobb területen elterjedt, a tájon belül diszjunkt areájú bennszülött berkenyefaj. Areája a felsőörsi, lovasi populációval a Balatonfelvidék keleti területeire is kiterjed. A legközelebbi populációja a nagyvázsonyi Minavölgyben él, légvonalban kb. 18 km-re a Felsőörs, Lovas határában talált populációktól. Innen (amely a lovasihoz hasonlóan szintén igen izolált előfordulás!) a Növénytárban csak Somlyay Lajossal és Alexander Sennikovval közös gyüjtéseink képezik a dokumentációs anyagot. NÉMETH (2013) ugyanakkor jelez egy 1959-es Boros-féle herbáriumi példányt (Boros Á., 1959.08.13. "Mina-tető" /BP448775/), amely jelenleg ugyancsak hiányzik a növénytári törzsgyüjteményből. 
A populációk számos egyedét genetikai mintagyűjtéssel és herbáriumi példányokkal dokumentáltam, melyeket az MTM Herbarium Carpato-Pannonicum ill. a Debreceni Egyetem gyűjteményeiben helyezek el.

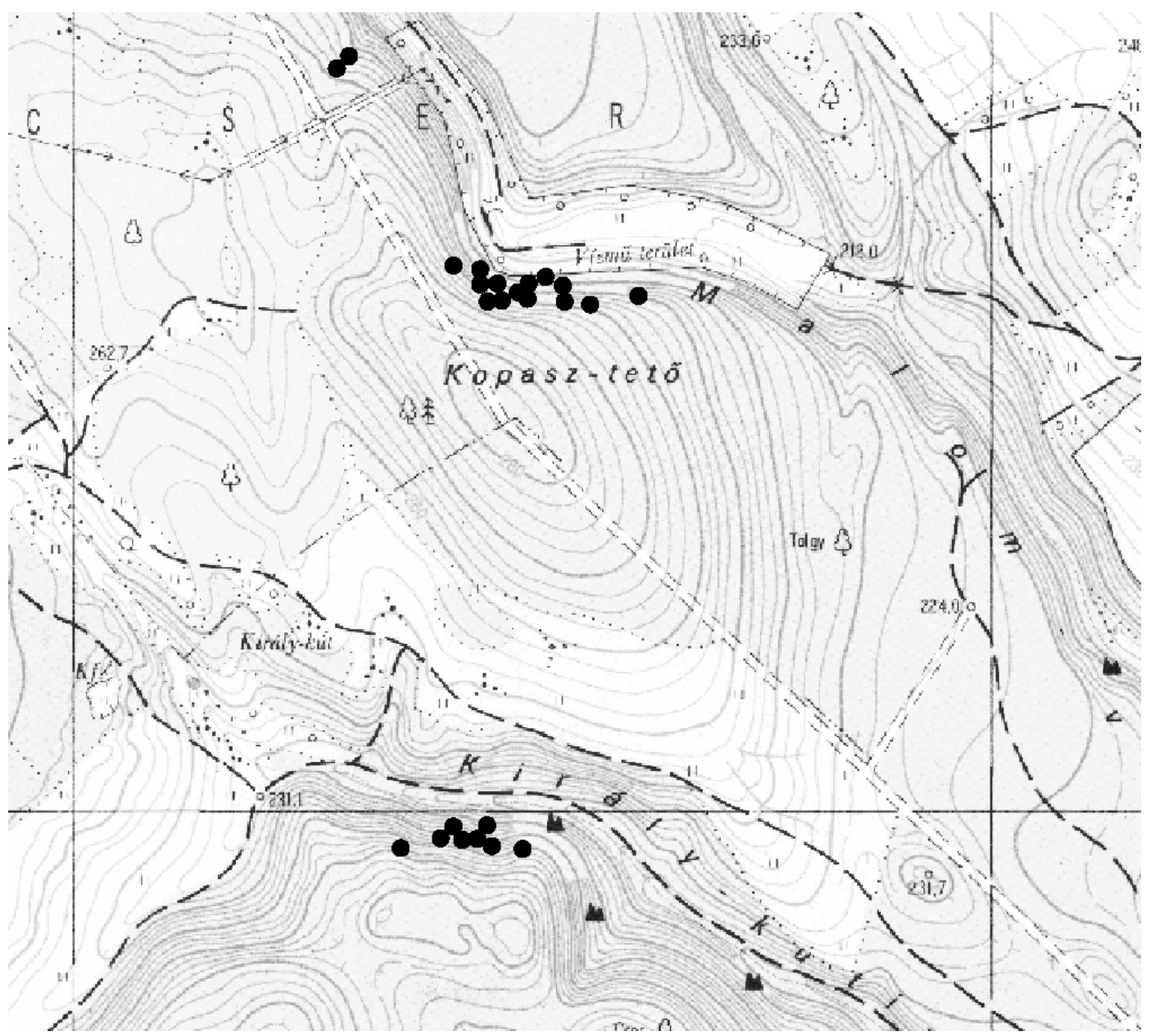

1. ábra. A Sorbus udvardyana elterjedése a felsőörsi Kopasz-tető, Malom-völgy és a lovasi Atyahegy, Királykúti-völgy térségében (a térképezett példányokat a fekete pontok jelzik).

Fig. 1. Distribution of the Sorbus udvardyana in the region of Felsőörs and Lovas, in the Balaton Uplands.

Az Atya-hegy és a Kopasz-tető élőhelyeinek természetességi állapota a korábbi feketefenyő telepítések ellenére, és az elmúlt évtizedek zavartalansága miatt meglepően jó. A Királykútivölgy és a Malom-völgy vízbázis védelmi okokból viszonylag zavartalan területek. Mind a Kopasz-tetőn, mind az Atya-hegyen megjelennek további értékes taxonok, így Carex alba, Coronilla coronata, C. vaginalis, Cotoneaster integerrimus, C. niger, Hippocrepis emerus, Leucanthemum margaritae, Sorbus danubialis, S. aria s.l., Scilla autumnalis, Veratrum nigrum, Viola collina. A terület legjelentősebb botanikai értéke azonban egyértelmúen a most közölt, jelentős egyedszámú Sorbus udvardyana populáció, amelynek megőrzése érdekében a terület természetvédelmi státuszának megerősítése (fokozottan védetté nyilvánítás, erdőtervek szintjén az érintetlenség elérése) lenne szükséges. A populáció további vizsgálata taxonómiai és növényföldrajzi szempontból is feltétlenül indokolt. Az új állomány taxonómiai 
elkülönülésének mértékéről, ill. a $S$. udvardyana taxonon belüli említett változatosság taxonómiai jelentőségéről csak a tervezett genetikai vizsgálatokat követően nyerhetünk biztos információkat.

\section{Köszönetnyilvánítás}

Köszönöm Somlyay Lajosnak a gyűjtött anyag átnézését és a kézirathoz füzött megjegyzéseit.

\section{Irodalom}

BARABITS E. (2007): A Sorbus bakonyensis (Jáv.) Kárp. taxonómiai revíziója - új berkenye fajok a magyar flórában. - Tilia 13: 5-48.

Borbás V. (1900): A Balaton tavának és partmellékének növényföldrajza és edényes növényzete. - A Balaton tudományos tanulmányozásának eredményei 1, Budapest, 432 pp.

Boros Á. (1957): Florisztikai jegyzetek 43. évf. 1957. - MTM, Tudománytörténeti Gyűjtemény, mscr.

JávorKA S. (1927): A Sorbus torminalis (L.) CR. magyar keverékfajai. - Magyar Botanikai Lapok 25: 83-90.

KÁRPÁTI Z. (1948): Megjegyzések néhány berkenyéről. - Agrártudományi Egyetem Kert- és Szőloogazdaságtudományi Karának közleményei 12: 119-159.

KÁRPÁTI Z. (1950a): Újabb taxonómiai vizsgálatok a Sorbus aria s. l. és a $S$. torminalis közé eső hazai berkenyéken. - Agrártudományi Egyetem Kert- és Szőlőgazdaságtudományi Karának közleményei 1: 31-52.

KÁRPÁTı Z. (1950b): A köztes alakok kérdésének növényföldrajzi es fejlődéstörténeti vonatkozásai Debreceni Egyetem Biológiai Intézetének Évkönyve 1: 189-197.

KÁRPÁTI Z. (1953): Dendrológiai jegyzetek VI. - Újabb adatok a hazai berkenyék ismeretéhez Agrártudományi Egyetem Kert- és Szőlőgazdaságtudományi Karának közleményei 1953: 81-88.

KÁRPÁTI Z. (1960): Die Sorbus-Arten Ungarns und der angrenzenden Gebiete. - Feddes Repertorium 62: 71-331.

Kováts D. (1998) Plant types of Sándor Jávorka in the Hungarian Natural History Museum in Budapest I. - Annales historico-naturales Musei nationalis hungarici 90: 115-132.

NÉMETH Cs. (2007): Új berkenye kisfaj a magyar flórában Sorbus tobani Németh. - Flora Pannonica 5: 173-184.

NÉmeth Cs. (2010) Taxonomic revision, typification and validation of Sorbus (Rosaceae) taxa in the herbarium Carpato-Pannonicum in Budapest I. - Acta Botanica Hungarica 52: 377-397.

NÉmETH Cs. (2012): Two new Sorbus (Rosaceae) species from the Bakony Mts, Hungary. - Acta Botanica Hungarica 54: 131-144.

NÉMETH Cs. (2013): Hibrid eredetű, bennszülött Sorbus aria s. l. × Sorbus torminalis taxonok (nothosubgenus Tormaria, S. latifolia agg.) elterjedése a Bakonyban. - Kitaibelia 18: 89-104.

NÉMETH Cs. (2014a): Sorbus-kutatások a Keszthelyi-hegység területén (Sorbus researches in the Keszthely Mountains). - In: Schmidt D., KovÁcs M. \& BARThA D. (szerk.), X. Aktuális Flóra- és Vegetációkutatás a Kárpát-medencében. pp. 64-65. (USB-kulcson terjesztett anyag)

NÉMETH Cs. (2014b): Apomiktikus Sorbus taxonok a Tapolcai-medence bazalt tanúhegyein (Distribution of apomictic Sorbus taxa on the basalt remnant hills of the Tapolca Basin). - In: SCHMIDT D., KovÁcS M. \& BARTha D. (szerk.), X. Aktuális Flóra- és Vegetációkutatás a Kárpát-medencében. p. 196. (USBkulcson terjesztett anyag)

Somlyay L. \& SEnNiKov, A. N. (2014): Atlas Florae Europaeae notes 23. The typification and revised taxonomic circumscription of Sorbus bakonyensis (Rosaceae), with a description of Sorbus udvardyana, a new apomictic species endemic to Hungary. - Phytotaxa 164: 265-275.

Beérkezett / received: 2014. 09. 28. • Elfogadva / accepted: 2014.11. 17. 